\title{
ИСТОРИЯ СТАНОВЛЕНИЯ АРБИТРАЖНЫХ СУДОВ В РОССИИ
}

В работе рассматривается история становления и развития арбитражных судов в России. Авторы придерживаются позиции о необходимости усовершенствования судоустройства, приведения к единообразию системы судов общей юрисдикции и арбитражных судов и инстанционной системы.

Ключевые слова: суд, арбитражный суд, торговый суд, арбитражные комиссии, экономические и хозяйственные споры.

\section{THE HISTORY OF THE FORMATION OF ARBITRATION COURTS IN RUSSIA}

The article provides a historical background on the formation and development of arbitration courts in the Russian Federation. The authors come to the conclusion that in the Russian Federation it is necessary to improve the judicial system, to bring to uniformity the system of general and arbitration courts.

Keywords: court, arbitration court, commercial court, arbitration commissions, economic and economic disputes. 
Арбитражное судопроизводство как самостоятельная, регламентируемая процессуальным законодательством, деятельность специальных судов появилось в России только в 1991 г. Однако в целом период развития судов по рассмотрению экономических споров имеет богатую историю.

Первым памятником русского законодательства, содержащим нормы о судах, разрешающих торговые споры, называют Уставную грамоту Новгородского князя Всеволода Мстиславовича 1135 г. [35, с. 273]. Следующим этапом развития коммерческого судопроизводства принято считать XVII в. [32, с. 111]. В 1667 г. в России был создан постоянно действующий коммерческий суд для рассмотрения купеческих споров [26, с. 16]. Дальнейшее развитие коммерческих судов связано с правлением Петра I, который Указом 1699 г. учредил в Москве Бурмистрскую Палату для рассмотрения споров по торговым и купеческим делам, а также деятельности промышленных людей [27]. В 1719 г. в России была учреждена Коммерц-коллегия, надзиравшая за торгами и торговыми действиями. В 1721 г. был учрежден Главный Магистрат, рассматривающий торговые, налоговые и другие дела экономического характера. С принятием в 1727 г. Устава суда таможенного по словесным прошениям были учреждены суды, рассматривающие споры из договоров купли-продажи, займе, хранении, перевозке и т.д. Взгляды исследователей на последующее развитие торговых судов расходятся. Так, А.А. Власов и другие полагают, что первый коммерческий суд был создан в Одессе в 1808 г. [24, с. 9]. Другие авторы отодвигают это событие к 1832 г., когда был принят Устав торгового судопроизводства и учреждены коммерческие суды. При проведении судебной реформы 1864 г. судоустройство и судопроизводство принципиально изменились [29, с. 32-34]. Была создана кардинально новая система судов [31, с. 45]. Однако, положения о торговых судах не были затронуты, Устав оставался самостоятельным источником права вплоть до 1917 г. [23, с. 147].

С 1917 г. в России началось реформирование правовой системы, были упразднены все государственные учреждения, в том числе и суды. В п. 1 декрета ВЦИК РСФСР «О суде» от 22 ноября 1917 г. № 1 указывалось: «упразднить... коммерческие суды, заменяя все эти установления судами, образуемыми на основании демократических выборов» [20]. В первые годы после Октябрьской революции в условиях слаборазвитых товарно-денежных отношений судебные споры между государственными предприятиями и учреждениями не допускались [19]. Разногласия между ними разрешались в административном порядке, необходимости в коммерческих судах не существовало. Переход к НЭПу потребовал отказа от административного способа разрешения хозяйственных споров. В 1922 г. был образован ведомственный арбитраж и арбитражные комиссии, однако, назвать их судами не представлялось возможным, так 
как они скорее являлись органами исполнительной власти. С 1922 г. хозяйственные споры между государственными учреждениями и предприятиями разных ведомств разрешались Высшей арбитражной комиссией при Совете Труда и Обороны (СТО) и арбитражными комиссиями при областных экономических совещаниях (ЭКО СО) [18]. На местах были созданы арбитражные комиссии при областных экономических совещаниях. Дальнейшее развитие органов, рассматривающих хозяйственные споры, связано с внедрением в плановую экономику хозяйственно-расчетных отношений и с развитием свободных договорных отношений. В 1931 г. принят акт, обязывающий все государственные, хозяйственные, кооперативные органы и предприятия оформлять взаимоотношения по купли-продаже, поставке товара, производству работ и оказанию услуг путем заключения договоров. Это послужили предпосылкой создания в 1931 г. государственного арбитража, разрешающего имущественные споры. Арбитраж существовал в двух видах: государственный и ведомственный. В государственном арбитраже разрешались споры предприятий и организаций различного административного подчинения, в ведомственном - споры предприятий, подчиненных одному министерству. В течение последующих 60 лет существования арбитража законодателем неоднократно предпринимались попытки его реструктуризации. Так, в 1960 г. было утверждено новое Положение о Государственном арбитраже, ему придан статус государственного комитета [17]. В 1970 г. принято постановление, согласно которому арбитраж должен был содействовать повышению эффективности рассмотрения хозяйственных споров, рационализации экономических связей, развитию и укреплению хозяйственного расчета [15]. До 1974 г. нижестоящие арбитражи не подчинялись вышестоящим. Арбитраж находился при исполнительном органе, система арбитражей была разбалансированной. Указанная проблема была решена в 1974 г. С этого времени Госарбитраж СССР был преобразован в союзно-республиканский орган, нижестоящие арбитражи стали подчиняться вышестоящим. Однако, государственный арбитраж все равно оставался органом исполнительной власти. С принятием Конституции СССР 1977 г., органы государственного арбитража получили статус конституционного органа, что потребовало совершенствования законодательства, регламентирующего его правой статус, компетенцию, цели и задачи [14]. Деятельность арбитража стала регулироваться Законом «О Государственном арбитраже СССР» 1979 г. и Правилами рассмотрения хозяйственных споров государственными арбитражами 1980 г., которые действовали до 1992 г. То есть государственный арбитраж в СССР и РСФСР имел неопределенную юридическую природу и неоднозначное положение в структуре государственного управления, осуществляя и судебные функции, и функции управления, оставаясь органом исполнительной власти. 
Следующим этапом развития системы арбитражных судов принято считать 1991-1995 гг. Как справедливо указывает М.К. Треушников [37, с. 12], точкой отсчета процесса замены государственных арбитражей судами является принятие закона «Об арбитражном суде» 1991 г. [12]. Развитие законодательства 1992-1994 гг. является первым этапом создания современной системы арбитражных судов. Политические и экономические изменения, происходящее в стране в целом, требовали принятия новых концептуальных законодательных актов: Конституции РФ [1], Гражданского кодекса РФ (далее - ГК РФ) [8]. В соответствии со ст. 127 Конституции РФ высшим судебным органом по разрешению экономических споров и иных дел, рассматриваемых арбитражными судами, а также органом, осуществляющим в предусмотренных фредеральным законом порядке процессуальный судебный надзор являлся Высший Арбитражный Суд Российской Федерации (далее - ВАС РФ). Формирование нового гражданского законодательства и опыт функционирования арбитражных судов в качестве органов правосудия определили необходимость изменения системы арбитражных судов. С учетом этого в 1995 г. были приняты федеральный конституционный закон «Об арбитражных судах в Российской Федерации» [6] и Арбитражный процессуальный кодекс РФ [11]. В результате реформы в России было создано 10 федеральных судебных округов, в каждом из которых учрежден окружной арбитражный суд, проверяющий судебные акты в кассационной инстанции. Местом постоянного пребывания федерального арбитражного суда Восточно-Сибирского округа (далее - AC ВСО) был утвержден Иркутск [9]. АС ВСО, как и другие арбитражные суды кассационной инстанции, создан по территориальному (географическому) принципу, его юрисдикция распространяется на Республику Бурятия, Саха (Якутия), Тыву, Хакасию, Красноярский и Забайкальский край, Иркутскую область. На его территории действуют Третий и Четвертый арбитражные апелляционные суды. Значимость данного суда очень высока, ежегодно в АС ВСО обращаются за защитой прав и интересов более пяти тысяч предпринимателей и юридических лиц.

В целях повышения эффективности деятельности арбитражных судов в 1997 г. была принята программа [10], позволяющая им утвердиться в качестве специализированных судов. Это стало предпосылкой создания нового звена арбитражной системы - арбитражных апелляционных судов. В соответствии с действующим Арбитражным процессуальным кодексом Российской Федерации 2002 г. [7] и федеральным конституционным законом 2003 г. [5] были созданы апелляционные суды, по два в каждом судебном округе.

Реформирование системы арбитражных судов на этом не закончилась. В 2013 г. в системе арбитражных судов был создан Суд по интеллектуальным правам [4]. В рамках дальнейшего развития системы 
арбитражных судов в 2014 г. произошло объединение Высшего Арбитражного и Верховного Судов [28, с. 77; 37, с. 91]. При этом, несмотря на учреждение единого высшего судебного органа, система судов общей юрисдикции и арбитражных судов так и не была приведена к единообразию. В доктрине неоднократно отмечалось, что системы этих судов имеют различное устройство: федеральные суды общей юрисдикции состоят из двух звеньев, а арбитражные суды - из трех. Отсутствие единообразия длительное время вызывало серьезную критику [25, с. 140]. Так, в судах общей юрисдикции дела в апелляции рассматривались судебными коллегиями областных и соответствующих им судов, в кассации - президиумами данных судов. То есть областные суды выступали в качестве судов первой, апелляционной и кассационной инстанции. В арбитражных же судах после принятия ФКЗ «Об арбитражных судах» и по настоящее время дела в порядке апелляции и кассации рассматривают отдельно выделенные суды - арбитражные апелляционные и окружные суды. Данные противоречия, выраженные в отсутствии единообразия по звеньям в судебной системе, противоречат ст. 19 и 46 Конституции РФ, поскольку ставят лиц, ищущих защиты своих прав, в неравное положение [39, с. 88-93; 40, с. 98-106]. Такое положение недопустимо, поскольку в единой судебной системе не должно быть принципиальных различий в устройстве судов и порядке пересмотра судебных актов. Для решения сложившейся проблемы учеными предлагалось реформировать действующую судебную систему, привести к единообразию инстанционную систему общих и арбитражных судов. При этом недостатки судебной системы не ограничивались отсутствием единообразия. Так, областные суды общей юрисдикции были не в состоянии рассматривать все дела по кассационным жалобам, как это делают арбитражные суды округов [25, с. 147]. В связи с перегруженностью президиумов судьи единолично рассматривали жалобы и решали вопрос, передавать их на коллегиальное рассмотрение или нет. В результате в подавляющем большинстве случаев судебное заседание не проводилось, дела не рассматривались [25, с. 34].

В судебной системе возникла необходимость преобразований, созвучных новому времени и глубоким фрормационным изменениям, происходящим и в правовой, и в общественной жизни [38, с. 19]. Для решения вышеизложенных проблем было предложено создать в системе судов общей юрисдикции окружные суды в качестве судов кассационной инстанции, по образу арбитражных судов, и освободить президиумы областных судов от данных полномочий [30, с. 4]. В связи с этим был детально проработан и принят федеральный конституционный закон от 29 июля 2018 г. № 1-ФКЗ [2]. На основании него в настоящее время в системе федеральных судов общей юрисдикции создаются структурно самостоятельные кассационные и апелляционные суды, за основу взята 
действующая система арбитражных судов. Они будут действовать в пределах территории соответствующих судебных кассационных и апелляционных округов. Всего создано 9 кассационных и 5 апелляционных судов общей юрисдикции. Так, в качестве суда апелляционной инстанции по жалобам, представлениям на судебные акты Иркутского областного суда будет выступать Пятый апелляционный суд общей юрисдикции, расположенный в г. Новосибирске. Осуществлять пересмотр судебных актов, принятых судом Иркутской области, а также судебных актов апелляционных судов общей юрисдикции, принятых по жалобам и представлениям на судебные акты указанного суда будет Восьмой кассационный суд общей юрисдикции, расположенный в г. Кемерово. Принципиальным отличием установленного порядка в системе судов общей юрисдикции от прежнего является четкое распределение между разными судами фрункций по проверке и пересмотру судебных постановлений в апелляционном и кассационном порядке, которые ранее были сконцентрированы в одних судах. Тем самым действующая система судов общей юрисдикции становится схожа с системой арбитражных судов [30, с. 4]. Реформирование судебной системы будет способствовать реализации в большей мере, чем в настоящее время, принципов независимости судей и равенства граждан и организаций перед законом и судом.

Таким образом, резюмируя вышеизложенное, можно сделать вывод, что процесс формирования арбитражных судов в России был весьма продолжительным, пройден путь от создания первых коммерческих судов и заканчивая учреждением единого высшего судебного органа по рассмотрению экономических споров. Основной задачей следующего этапа является совершенствование правосудия в арбитражных судах, обеспечение его независимости и эффрективности, быстрое и качественное разрешение экономических споров, повышение доверия участников рынка и международного сообщества к системе арбитражных судов.

\section{Список использованной литературы и источников}

1. Конституция Российской Федерации : от 12.12.1993 г. (с послед. изм. и доп.) // Собрание законодательства РФ. - 2014. — № 31. - Ст. 4398.

2. О внесении изменений в федеральный конституционный закон «О судебной системе Российской Федерации» и отдельные федеральные конституционные законы в связи с созданием кассационных судов общей юрисдикции и апелляционных судов общей юрисдикции : федер. конст. закон РФ от 29 июля 2018 г. № 1-ФКЗ // Собрание законодательства РФ. — 2018. — № 31. - Ст. 4811.

3. О Верховном Суде Российской Федерации и прокуратуре Российской Федерации : федер. конст. закон РФ от 5 февраля 2014 г. № 2-ФКЗ // Собрание законодательства РФ. - 2014. - № 6. - Ст. 548.

4. О внесении изменений в федеральный конституционный закон «О судебной системе Российской Федерации» и федеральный конституционный закон «Об арбитражных судах в Российской Федерации» в связи с созданием в систе- 
ме арбитражных судов Суда по интеллектуальным правам : федер. конст. закон от 6 декабря 2011 г. № 4-ФКЗ (в ред. от 05 февр. 2014 г.) // Собрание законодательства РФ. - 2011. - № 50. - Ст. 7334.

5. О внесении изменений и дополнений в федеральный конституционный закон об арбитражных судах в Российской Федерации : федер. конст. закон от 4 июля 2003 г. № 4-ФКЗ (в ред. от 4 июня 2014 г.) // Собрание законодательства РФ. - 2003. - № 27 (ч. І). — Ст. 2699.

6. Об арбитражных судах в Российской Федерации : федер. конст. закон от 28 апреля 1995 г. № 1-ФКЗ (ред. от 29 июля 2018 г.) // Собрание законодательства РФ. - 1995. - № 18. - Ст. 1589.

7. Арбитражный процессуальный кодекс Российской Федерации от 24 июля 2002 г. № 95-Ф3 (ред. от 25 дек. 2018 г.) // Собрание законодательства РФ. 2002. - № 30. - Ст. 3012.

8. Гражданский кодекс Российской Федерации (ч. 1) от 30 ноября 1994 г. № 51-Ф3 (ред. от 27 дек. 2018 г.) // Собрание законодательства РФ. — 1994. № 32. - Ст. 3301.

9. Об утверждении мест постоянного пребывания федеральных арбитражных судов округов: Постановление Пленума Высшего Арбитражного Суда РФ от 3 июля 1995 г. № 26 // Вестник Высшего Арбитражного Суда РФ. - 1995. — № 11.

10. Об утверждении Программы повышения эффективности деятельности арбитражных судов в Российской Федерации в 1997-2000 годах и Плана мероприятий по реализации Программы повышения эффективности деятельности арбитражных судов Российской Федерации в 1997-2000 годах : приказ Высшего Арбитражного Суда РФ от 18 сентября 1997 г. № 14 [Электронный ресурс] // КонсультантПлюс. - Режим доступа : http://www.consultant.ru/cons/cgi/online. cgi?req=doc\&base $=$

11. Арбитражный процессуальный кодекс Российской Федерации от 5 мая 1995 г. № 70-Ф3 // Собрание законодательства РФ. — 1995. — № 19. - Ст. 1709.

12. Об арбитражном суде: закон РФ от 4 июля 1991 г. № 1543-1 // Ведомости Съезда народных депутатов РСФСР и Верховного Совета РСФСР. - 1991. № 30. - Ст. 1013.

13. О государственном арбитраже в СССР: закон СССР от 30 ноября 1979 г. № 1163-Х // Ведомости ВС СССР. - 1979. — № 49. - Ст. 844.

14. Конституция (Основной Закон) Союза Советских Социалистических Республик от 7 октября 1977 года // Ведомости Верховного Совета СССР. 1977. — № 41. - Ст. 617.

15. О повышении роли органов государственного арбитража и арбитражей министерств и ведомств в народном хозяйстве: постановление Совмина СССР от 7 августа 1970 г. № 646 // Собрание постановлений Правительства СССР. 1970. - № 15. - Ст. 122.

16. Об утверждении Положения о Государственном арбитраже при Совете Министров СССР: Постановление Совмина СССР от 17 августа 1960 г. № 892 // Собрание постановлений Правительства СССР. - 1960. - № 15. - Ст. 127.

17. Положение о государственном арбитраже: постановление ЦИК ССР № 5 от 28 декабря 1931 г. // Собрание законов СССР. - 1931. - № 26. - Ст. 203.

18. Положение о порядке разрешения имущественных споров между государственными учреждениями и предприятиями: декрет ВЦИК, СНК РСФСР От 21 сентября 1922 г. // Собрание узаконений РСФСР. — 1922. - № 60. - Ст. 769. 
19. О суде: декрет ВЦИК от 7 марта 1918 г. № 2 // Собрание узаконений РСФСР. - 1918. - № 26. - Ст. 420.

20. О суде: декрет ВЦИК РСФСР от 22 ноября 1917 г. № 1 // Собрание постановлений Правительства РСФСР. — 1917. - № 4. - Ст. 50.

21. Борисова Е. А. Обжалование не вступивших в законную силу судебных решений в гражданском процессе / Е. А. Борисова // Российская юстиция. 2003. - № 10. - С. 18-20.

22. Бурдина Е. В. Развитие судебной системы в условиях информационного общества / Е. В. Бурдина // Российское правосудие. - 2018. - № 7 (147). C. 21-22.

23. Васьковский Е. В. Учебник гражданского процесса : учебник / Е. В. Васьковский. - М. : Изд. бр. Башкамовых, 1914. - 372 с.

24. Власов А. А. Арбитражный процесс : учебник / А. А. Власов. - М. : Юрайт, 2018. $-362 \mathrm{c}$.

25. Жуйков В. М. О некоторых проблемах развития процессуального законодательства и законодательства о судоустройстве / В. М. Жуйков // Журнал российского права. - 2017. - № 8. - С. 135-150.

26. Законодательство царя Алексея Михайловича. Извлечение из книги Соборное уложение 1649 года / под ред. В. А. Томсинова. - М. : Зерцало, 2011. $211 \mathrm{c.}$

27. Извлечение из книги Законодательство Екатерины I и Петра II / под ред. В. А. Томсинова. - М. : Зерцало, 2011. - 217 с.

28. Комаров А. С. Основные пути развития российской судебной системы и Верховного Суда РФ: проблемы и перспективы реформирования / А. С. Комаров // Ростовский научный журнал. - 2017. — № 4. - С. 114-124.

29. Курас С. Л. О некоторых аспектах реформирования суда на страницах «Журнала Министерства юстиции» / С. Л. Курас // Правовая политика современной России: реалии и перспективы : материалы Междунар. науч.-практ. конф., посвящ. 150-летию земской и судебной реформ в России. Иркутск, 8 нояб. 2014 г. - Иркутск : ИГУ, 2014. - С. 32-34.

30. Курас Т. Л. Реформирование российской судебной системы: история и перспективы / Т. Л. Курас // Проблемы современного законодательства России и зарубежных стран : материалы VI Междунар. науч.-практ. конф., г. Иркутск, 8 декабря 2017 г. : в 2 т. / отв. ред. С. И. Суслова. - Иркутск : Иркутский институт (филиал) ВГУЮ (РПА Минюста России), 2018. - Т. 1. - С. 3-4.

31. Курас Т. Л. Реформирование судебной системы в России: исторический опыт и современные проблемы. Региональный аспект / Т. Л. Курас // Сибирский юридический вестник. - 2014. - № 4. - С. 45-53.

32. Матаева М. Х. Развитие судебной системы в России и на Постсоветском пространстве / М. Х. Матаева // Евразийский юридический журнал. - 2017. № 11 (114). - С. 76-78.

33. Меряшев М. Л. Исторические аспекты развития судебной системы (IX-XV вв.) / М. Л. Меряшев // Евразийский научный журнал. - 2017. № 5. - C. 12-16.

34. Нагорная Э. Н. Производство в кассационной инстанции арбитражного суда: сравнительный комментарий Арбитражного процессуального кодекса Российской Федерации / Э. Н. Нагорная. - 2-е изд., перераб. и доп. - М. : Юстицинформ, 2003. - 144 с. 
35. Российское законодательство X-XX вв. : в 9 т. / под ред. О. И. Чистякова. - Т. 1: Рукописание князя Всеволода. ХІІІ в. - М. : Юрид. лит., 1984. - 482 с.

36. Свирин Ю. А. Об истории арбитражного процесса / Ю. А. Свирин // Законодательство и экономика. - 2016. - № 1. - С. 4-5.

37. Треушников М. К. Арбитражный процесс / М. К. Треушников. - М. : Городец-издат, 2001. - $784 \mathrm{c.}$

38. Чесных И. И. Перспективы развития российской системы в 2018-2020 гг. I И. И. Чесных // Государство и право в XXI веке. - 2017. — № 3. - С. 39-41.

39. Шерстюк В. М. Реорганизация судебной системы: а дальше что? / В. М. Шерстюк // Закон. - 2014. - № 3. - С. 88-93.

40. Ярков В. В. Объединения высших судов: ожидания и последствия / В. В. Ярков // Закон. - 2014. - № 3. - С. 98-106.

\section{Информация об авторах}

Курас Татьяна Леонидовна — кандидат исторических наук, доцент, кафедра судебного права, Юридический институт, Иркутский государственный университет, 664003, г. Иркутск, ул. К. Маркса, 1; e-mail: tanya_kuras@mail.ru

Шишкина Наталья Эдуардовна - доктор юридических наук, профрессор, кафедра конституционного права и теории права, Юридический институт, Иркутский государственный университет, 664003, г. Иркутск, ул. К. Маркса, 1; e-mail: shishkina1957@rambler.ru

Климентьева Лиана Владиславовна - помощник заместителя председателя Арбитражного суда Восточно-Сибирского округа, магистр, Юридический институт, Иркутский государственный университет, 664003, г. Иркутск, ул. К. Маркca, 1; e-mail: be_queen@mail.ru

\section{Authors}

Tatyana L. Kuras - PhD in History, Associate Professor, Department of Justice, Law Institute, Irkutsk State University, 1 K. Marx St., 664003, Irkutsk, Russia; e-mail: tanya_kuras@mail.ru

Natalia E. Shishkina - Doctor of Law, Professor, the Department of Constitutional Law and Theory of Law, Law Institute, Irkutsk State University, 1 K. Marx St., 664003, Irkutsk, Russia; e-mail: shishkina1957@rambler.ru

Liana V. Klimenteva - Assistant the Vice-President of the Arbitration Court of the East Siberian District, Magistracy, Law Institute, Irkutsk State University, 1 K. Marx St., 664003, Irkutsk, Russia; e-mail: be_queen@mail.ru 